\title{
Spontaneous rupture of splenic artery psuedoaneurysm into stomach: an uncommon presentation
}

\author{
Rajesh Sisodiya, ${ }^{1}$ Sampath Kumar $^{2}$
}

${ }^{1}$ Department of General Surgery, Kasturba Hospital, Udupi, Karnataka, India ${ }^{2}$ Department of General Surgery, Kasturba Hospital, Manipal University, Udupi, Karnataka, India

\section{Correspondence to} Dr Rajesh Sisodiya, rajeshnidhi@gmail.com
To cite: Sisodiya $R$ Kumar S. BMJ Case Rep Published online: [please include Day Month Year] doi:10.1136/bcr-2013200372

\section{DESCRIPTION}

A young man with chronic calcific pancreatitis presented with passage of black tarry stool. He had haematemesis 2 days prior. Haemoglobin was $5 \mathrm{~g} / \mathrm{dL}$, haematocrit 15.6 with total leucocyte count $35100 \mathrm{cells} / \mu \mathrm{L}$. We suspected oesophageal variceal bleed. Endoultrasound showed $8.5 \times 5.5 \times 6 \mathrm{~cm}$ psuedocyst with echogenic areas and grade 1 oesophageal varices without bleeding. Diagnosis of acute on chronic pancreatitis with infected pseudocyst was made and the patient was transfused with blood and was treated conservatively. The patient had profuse haematemesis on the third day of hospitalisation. We suspected splenic artery psuedoaneurysm with rupture into the stomach. CT abdomen showed extravasation of contrast from the splenic artery (figure 1). CT embolisation was tried but failed. Immediately the patient was taken for laparotomy. Gastrocolic omentum forming the anterior wall of the pseudocyst was opened and three fist full clots were removed (figure 2). Splenic

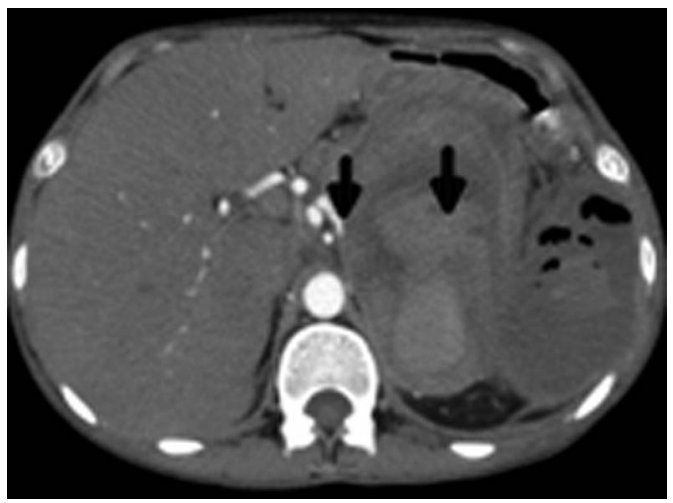

Figure $1 \mathrm{CT}$ abdomen showing contrast extravasation from splenic artery.

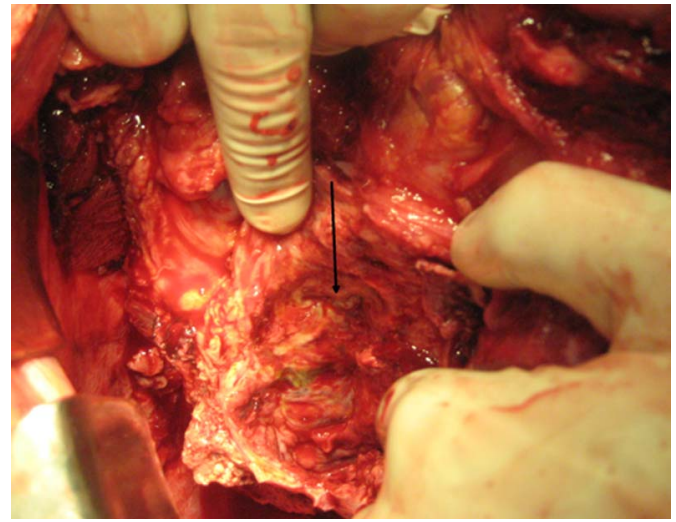

Figure 2 Psuedoaneurysm after splenic artery ligation, splenectomy and adequate saline lavage.

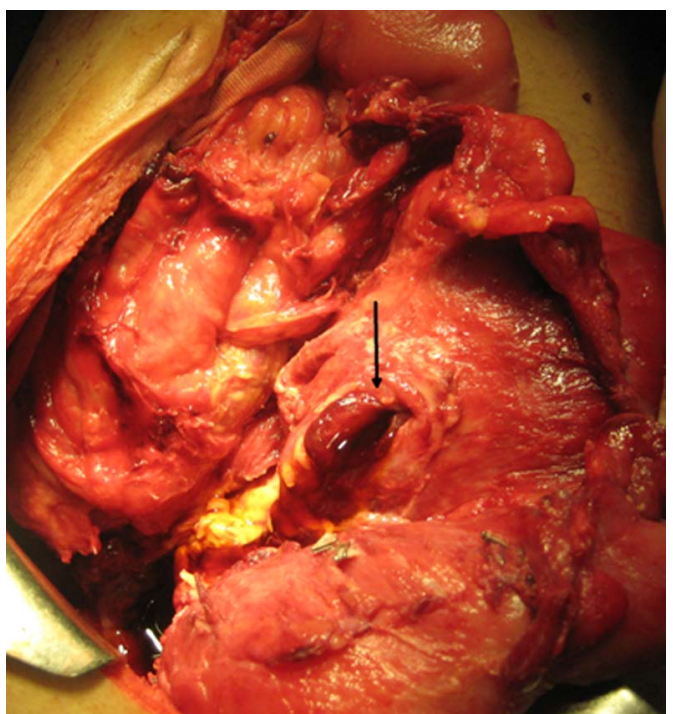

Figure 3 Stomach perforation by psuedoaneurysm.

vein and artery were transfixed, pancreatic duct was ligated, and distal remnant pancreas and spleen were removed. Approximately $2.5 \mathrm{~cm}$ rent was seen in the stomach (figure 3). After adequate lavage with warm saline the stomach rent was closed and drains were placed. The patient did not develop pancreatic fistula and had uneventful recovery.

\section{Learning points}

- The diagnosis of ruptured splenic artery aneurysms into the gastrointestinal tract can sometimes be missed, especially in alcoholics and in patients with pancreatitis because several more common causes of bleeding could exist in these populations. ${ }^{1}$

- Since most aneurysms occur in the distal portion, often in close association with the hilum of the spleen, splenectomy is recommended. However, in the setting of pancreatitis, en bloc removal of the involved pancreas including the aneurysm is recommended. ${ }^{23}$

- With progressive expansion, a pseudoaneurysm may ultimately rupture into the gastrointestinal tract, the free peritoneal cavity, or, rarely, into the pancreatic duct. ${ }^{4}$ Rupture usually occurs into the lesser sac (including a pseudocyst) initially.

- Transcatheter embolisation is the treatment of choice in splanchnic artery aneurysms and pseudoaneurysms. ${ }^{6}$ 
Competing interests None.

Patient consent Obtained.

Provenance and peer review Not commissioned; externally peer reviewed.

\section{REFERENCES}

1 Marks IN, Banks S, Louw JH, et al. Peptic ulceration and gastrointestinal bleeding in pancreatitis. Gut 1967;8:253-9.
2 Bivins BA, Sachatello CR, Chuang VP, et al. Haemosuccus pancreaticus (haemoductal pancreatitis): gastrointestinal haemorrhage due to rupture of splenic artery aneurysm into the pancreatic duct. Arch Surg 1978:113:751-3.

3 Luns JA, Schow PD, Knight L. Splenic artery aneurysm pancreatic duct fistula. Am J Surg 1980;139:430-1.

4 Kane MG, Krejs GJ. Pancreatic pseudocyst. In: Stollerman GH.ed.Advances in internal medicine. Vol. 29. Chicago: Year Book Medical, 1984:271-96.

5 Sandblom P. Gastrointestinal hemorrhage through the pancreatic duct. Ann Surg 1970;171:61-6.

6 Baker KS, Tisnado J, Cho SR, et al. Splanchnic artery aneurysms and pseudo aneurysms: transcatheter emboiisation. Radiology 1987;163:135-9.

Copyright 2013 BMJ Publishing Group. All rights reserved. For permission to reuse any of this content visit

http://group.bmj.com/group/rights-licensing/permissions.

BMJ Case Report Fellows may re-use this article for personal use and teaching without any further permission.

Become a Fellow of BMJ Case Reports today and you can:

- Submit as many cases as you like

- Enjoy fast sympathetic peer review and rapid publication of accepted articles

- Access all the published articles

- Re-use any of the published material for personal use and teaching without further permission

For information on Institutional Fellowships contact consortiasales@bmjgroup.com

Visit casereports.bmj.com for more articles like this and to become a Fellow 